\title{
Characterizing Water Use Efficiency and Water Deficit Responses in Apple (Malus $\times$ domestica Borkh. and Malus sieversii Ledeb.) M. Roem.
}

\author{
Carole L. Bassett ${ }^{1}$ and D. Michael Glenn \\ USDA, Agricultural Research Service, Appalachian Fruit Research Station, 2217 Wiltshire Road, \\ Kearneysville, WV 25430 \\ Philip L. Forsline \\ USDA, Agricultural Research Service, Plant Genetic Resources Unit, 630 W. North Street, \\ Geneva, NY 14456-0462 \\ Michael E. Wisniewski \\ USDA, Agricultural Research Service, Appalachian Fruit Research Station, 2217 Wiltshire Road, \\ Kearneysville, $W V 25430$ \\ Robert E. Farrell, Jr. \\ Pennsylvania State University, Department of Biology, 1031 Edgecomb Avenue, York, PA 17403 \\ Additional index words. drought, leaf area, leaf length, leaf width, leaf perimeter, stomata length, \\ stomata density, suppression subtractive hybridization, tissue-specific gene expression
}

\begin{abstract}
Reduced availability of water for agricultural use has been forecast for much of the planet as a result of global warming and greater urban demand for water in large metropolitan areas. Strategic improvement of water use efficiency (WUE) and drought tolerance in perennial crops, like fruit trees, could reduce water use without compromising yield or quality. We studied water use in apple trees using 'Royal Gala', a relatively water use-efficient cultivar, as a standard. To examine whether genes useful for improving WUE are represented in a wild relative genetically close to $\mathrm{M}$. $\times$ domestica, we surveyed Malus sieversii for traits associated with WUE and drought resistance using material collected from xeric sites in Kazakhstan. This collection has been maintained in Geneva, NY, and surveyed for various phenotypes and has been genetically characterized using simple sequence repeats (SSRs). These data suggest that most of the diversity in this population is contained within a subpopulation of 34 individuals. Analysis of this subpopulation for morphological traits traditionally associated with WUE or drought resistance, e.g., leaf size and stomata size and arrangement, indicated that these traits were not substantially different. These results imply that some of the genetic diversity may be associated with changes in the biochemistry, uptake, and/or transport of water, carbon, or oxygen that have allowed these trees to survive in water-limited environments. Furthermore, genes responding to drought treatment were isolated from 'Royal Gala' and categorized according to the biological processes with which they are associated. A large fraction of upregulated genes from roots were identified as stress-responsive, whereas genes from leaves were for the most part associated with photosynthesis. We plan to examine expression of these genes in the $M$. sieversii population during water deficit in future studies to compare their patterns of expression with 'Royal Gala'.
\end{abstract}

According to apple historian, Dan Bussey, there were nearly 16,000 varieties of apple in North America during the last four centuries; however, by 1904 , less than half of those could be identified in cultivation. Current estimates indicate that only 15 named varieties account for $90 \%$ of those available in grocery stores or markets (Nabhan, 2008).

Received for publication 28 Feb. 2011. Accepted for publication 17 May 2011.

We thank Sharon Jones and Jing Ma for their excellent technical assistance.

Mention of a trademark, proprietary product, or vendor does not constitute a guarantee or warranty of the product by the U.S. Dept. of Agriculture and does not imply its approval to the exclusion of other products or vendors that also may be suitable "Improvement of Horticultural Crops for Abiotic Stress Tolerance."

This paper was part of the colloquium "Improvement of Horticultural Crops for Abiotic Stress Tolerance" held 5 Aug. 2010 at the ASHS Conference, Palm Desert, CA, sponsored by the Vegetable Breeding (VGBR) Working Group, and co-sponsored by the Environmental Stress Physiology (STRS) Working Group.

${ }^{1}$ To whom reprint requests should be addressed; e-mail Carole.Bassett@ars.usda.gov.
Apples are believed to have originated in China, carried first by mammals (smallerfruited varieties by birds) over the western mountains of China and then by humans over the silk road trade routes into Europe. The modern cultivated apple (Malus $\times$ domestica Borkh.) is believed to have been domesticated in Turkestan, now Kazakhstan, Kyrgyzstan, Uzbekistan, Turkmenistan, and Tajikistan (Harris et al., 2002). Although there has been some confusion regarding the taxonomy of the cultivated apple (summarized in Harris et al., 2002), most taxonomists agree that Malus sieversii is the most closely related species (Mabberley et al., 2001; Robinson et al., 2001; Veslaco et al., 2010; Zhou and Li, 2000) and the likely progenitor.

Genetic and polymorphic characterization of $M$. sieversii has been reported by a number of laboratories. Volk et al. (2005) characterized populations of $M$. sieversii collected from two sites in Kazakhstan using SSRs and assessment of fruit quality and disease resistance/susceptibility. They were able to establish a "core" subset of $\approx 35$ individuals within each population that captured greater than $90 \%$ of the genetic and phenotypic di- versity. In another study, traits such as tree height/diameter, flower arrangement, fruit development and morphology, and pollen morphology were assessed in different accessions of $M$. sieversii populations from diverse regions in China (Yan et al., 2008). Analysis of these data along with random amplified polymorphic DNA results indicated that most of the genetic variation was within one population rather than among the populations sampled.

Human selection of apples has focused mainly on fruit quality traits and disease resistance. Although apples are grown in a wide variety of sites within the temperate zone, little direct selection for tolerance to abiotic stresses has taken place over the history of cultivation. Furthermore, few studies of abiotic stress resistance have been reported. A thorough study of drought responses of six apple species, including $M$. sieversii, was reported by Jinghui et al. (1996). Based on leaf area index, stomata density, osmotic permeability of leaf cytoplasmic membranes, root surface area, and free proline content, they concluded that Malus toringoides was the most drought-resistant species followed by $M$. sieversii and $M$. transitoria. 
Numerous physical and biological impacts are predicted by the current global warming model (Easterling et al., 2000). These include an increase in the global mean temperature, an increase in extreme weather phenomena, i.e., heavy precipitation in some areas with attendant flooding and low precipitation in other regions leading to widespread droughts, and alterations in survivability of various land-based organisms (for example, Breshears et al., 2005). In fact, increased tree mortality resulting from water deficit conditions is one of the more significant predicted responses to global climate change (Adams et al., 2009). Whether these changes reflect natural climate cycles or anthropogenic influence (or both) is not clearly understood at present; however, regardless of the origins of climate change, the fact that change is occurring has been well documented (Cooter and Leduc, 1995; Dai et al., 1998).

Drought resistance is used here as a general term and refers to the ability of one genotype to yield better than another during severe drought stress. Resistance can be realized through different strategies plants use to survive dehydration. A common mechanism is termed drought avoidance and refers to a plant's ability to maintain effective water status under dehydrative conditions (Blum, 2005). An example of this type of strategy would be development of longer roots to access moisture in drying soils or alterations in stomata structure/function to reduce water loss. Another strategy used for survival in xeric environments is the development of dehydration tolerance, i.e., the ability to maintain function in a desiccated state. This type of strategy is exemplified by the accumulation of osmoprotectants in response to dehydrative conditions.

We have undertaken a long-term study of drought resistance in apple using $M . \times$ domestica 'Royal Gala' as our standard for comparison based on previous identification of expressed sequence tags (ESTs) responding to drought in this cultivar (Wisniewski et al., 2008). Our primary goal is to identify potentially droughtresistant/-tolerant or improved WUE accessions of its close relative, $M$. sieversii. The specific objectives of the present study are to identify morphological variation potentially correlated with WUE and to identify genes from 'Royal Gala' (serving as a benchmark cultivar) that respond to water deficit. Based on these and other planned studies with $M$. sieversii, accessions of interest will be developed by clonal propagation and analyzed for drought-responsive gene expression for comparison to 'Royal Gala'. We expect to identify differences in gene responses (qualitative and quantitative) among the $M$. sieversii introductions that correlate with WUE and/or drought resistance. Such traits could be rapidly introgressed into commercially important apple cultivars to enhance tree survival during water deficit periods, to improve survival of newly planted seedlings, and to reduce dependency on irrigation.

\section{MATERIALS AND METHODS}

Orchard plots. The USDA National Malus Germplasm Collection in Geneva,
NY (lat. $42^{\circ} 52^{\prime} \mathrm{N}$, long. $76^{\circ} 59^{\prime} \mathrm{W}$, elevation $151 \mathrm{~m}$ ) provided plant material from the core $M$. sieversii population. The seeds were collected in Kazakhstan in 1995 and seedlings planted in Geneva in 1997 (Forsline et al., 2003). Thirty-four accessions from a xeric site in Kazakhstan (site 6.01) were selected for study (Volk et al., 2005) along with 'Royal Gala' for comparison with a commercially important cultivar. All plant material from Geneva, NY, was planted in three double rows with $1.8-\mathrm{m}$ spacing between rows and with $1.5-\mathrm{m}$ in-row spacing. All trees received conventional pest control and light pruning. A complete list of the trees sampled in this study can be found in Glenn and Bassett (2011).

Leaf measurements. Plant material from the core collection was sampled in the late summer of 2005 and leaf area, leaf length and width, and leaf perimeter were measured with a Model CI-203 leaf area meter (CID BioScience Inc., Camas, WA) on fully expanded leaves at approximately the same branch position from five current year's shoots of approximately equal length per tree. Leaf number per branch was determined by counting from the smallest visible leaf at the shoot tip to the base of the current year's shoot growth.

Table 1. Leaf characteristics of Malus sieversii from Kazakhstan site 6.01.

\begin{tabular}{|c|c|c|c|c|c|}
\hline $\begin{array}{l}\text { Plant } \\
\text { introduction ID }\end{array}$ & $\begin{array}{c}\text { Old accession } \\
\text { ID }\end{array}$ & $\begin{array}{c}\text { Leaf } \\
\text { length }^{z, y}(\mathrm{~cm})\end{array}$ & $\begin{array}{c}\text { Leaf } \\
\text { width }^{\mathrm{z}, \mathrm{y}}(\mathrm{cm})\end{array}$ & $\begin{array}{c}\text { Leaf } \\
\text { perimeter }^{\mathrm{z}, \mathrm{y}}(\mathrm{cm})\end{array}$ & $\begin{array}{c}\text { Leaf } \\
\operatorname{area}^{\mathrm{z}, \mathrm{y}}\left(\mathrm{cm}^{2}\right)\end{array}$ \\
\hline PI657028 & GMAL3682.e & 6.72 abcdefg & 3.48 ef & $16.84 \mathrm{bcd}$ & 15.89 cdef \\
\hline PI657029 & GMAL3682.f & $5.90 \mathrm{cdefgh}$ & $3.72 \mathrm{ef}$ & $15.70 \mathrm{cde}$ & 15.24 def \\
\hline PI657030 & GMAL3682.k & $8.36 \mathrm{ab}$ & 4.14 cdef & $20.40 \mathrm{abc}$ & $21.8 \mathrm{a}$ bcde \\
\hline PI657031 & GMAL3683.d & $7.90 \mathrm{abcd}$ & 4.24 cde & $20.26 \mathrm{abcd}$ & 21.91 abcde \\
\hline PI657033 & GMAL3683.i & 7.40 abcdef & 4.3 cde & $19.30 \mathrm{abcd}$ & 21.53 abcde \\
\hline PI657034 & GMAL3683.n & 7.13 abcdefg & $3.69 \mathrm{ef}$ & $17.92 \mathrm{abcd}$ & 17.35 bcdef \\
\hline- & GMAL3683.o & $4.26 \mathrm{~h}^{\mathrm{x}}$ & $2.65 \mathrm{f}$ & $11.26 \mathrm{e}$ & $8.26 \mathrm{f}$ \\
\hline PI657035 & GMAL3684.a & $\overline{6.99 \mathrm{ab}} \mathrm{cdefg}$ & $\overline{3.91 \mathrm{def}}$ & $\overline{18.10 \mathrm{abcd}}$ & $\overline{19.08}$ abcde \\
\hline PI657036 & GMAL3684.b & $6.76 \mathrm{abcdefg}$ & 4.25 cde & $18.26 \mathrm{abcd}$ & 19.76 abcde \\
\hline PI657037 & GMAL3684.1 & $8.18 \mathrm{abc}$ & 4.70 bcde & $21.16 \mathrm{ab}$ & $26.09 \mathrm{ab}$ \\
\hline PI657038 & GMAL3685.d & 7.16 abcdefg & 4.42 cde & $19.22 \mathrm{abcd}$ & 22.32 abcde \\
\hline PI657039 & GMAL3685.e & 6.82 abcdefg & $4.17 \mathrm{cdef}$ & $18.48 \mathrm{abcd}$ & 21.02 abcde \\
\hline PI657040 & GMAL3685.f & 5.83 cdefgh & 3.68 ef & $15.90 \mathrm{cde}$ & 14.96 ef \\
\hline PI657042 & GMAL3687.d & $8.73 \mathrm{a}$ & $4.62 \mathrm{bcde}$ & $22.32 \mathrm{a}$ & $26.28 \mathrm{ab}$ \\
\hline PI657045 & GMAL3688.n & $\overline{7.53 \text { abcde }}$ & $4.61 \mathrm{bcde}$ & $\overline{20.15 \mathrm{abcd}}$ & 23.69 abcde \\
\hline PI657046 & GMAL3689.c & 7.16 abcdefg & 4.45 cde & $19.40 \mathrm{abcd}$ & 22.05 abcde \\
\hline PI657049 & GMAL3689.n & 6.56 abcdefgh & $4.25 \mathrm{cde}$ & $17.48 \mathrm{abcd}$ & 20.13 abcde \\
\hline PI657050 & GMAL3689.p & $4.90 \mathrm{gh}$ & $5.57 \mathrm{abc}$ & $18.04 \mathrm{abcd}$ & 18.89 abcde \\
\hline PI657051 & GMAL3690.d & $5.15 \mathrm{fgh}$ & $6.74 \mathrm{a}$ & $19.54 \mathrm{abcd}$ & $25.21 \mathrm{abcd}$ \\
\hline PI657052 & GMAL3690.o & 5.76 defgh & $\overline{3.80 \mathrm{def}}$ & $15.62 \mathrm{cde}$ & $15.65 \mathrm{cdef}$ \\
\hline PI657055 & GMAL3691.j & 6.59 abcdefg & 4.56 bcde & $18.32 \mathrm{abcd}$ & 20.93 abcde \\
\hline PI657056 & GMAL3691.m & $7.88 \mathrm{abcd}$ & 4.69 bcde & $20.80 \mathrm{abc}$ & $25.56 \mathrm{abc}$ \\
\hline PI657067 & GMAL3975.d & $4.92 \mathrm{gh}$ & $6.04 \mathrm{ab}$ & $16.24 \mathrm{bcd}$ & 23.7 abcde \\
\hline PI657068 & GMAL3975.g & 6.32 bcdefgh & 3.52 ef & $15.76 \mathrm{cde}$ & $15.13 \mathrm{def}$ \\
\hline PI657069 & GMAL3975.k & 6.45 abcdefgh & $4.11 \mathrm{cdef}$ & $17.76 \mathrm{abcd}$ & 18.14 bcde \\
\hline PI657070 & GMAL3975.1 & 7.60 abcde & $4.09 \mathrm{cdef}$ & $19.66 \mathrm{abcd}$ & 21.45 abcde \\
\hline PI657071 & GMAL3975.m & 7.50 abcdef & $4.21 \mathrm{cdef}$ & 19.54 abcd & 21.51 abcde \\
\hline PI657073 & GMAL3989.f & 7.99 abcd & $5.37 \mathrm{abcd}$ & $22.22 \mathrm{a}$ & $28.46 \mathrm{a}$ \\
\hline PI657074 & GMAL3989.k & $6.01 \mathrm{bcdefgh}$ & 4.77 bcde & $\overline{17.18 \mathrm{abcd}}$ & $\overline{20.95 \text { abcde }}$ \\
\hline PI657075 & GMAL3999.b & 5.81 cdefgh & $3.71 \mathrm{ef}$ & $15.88 \mathrm{cde}$ & $15.2 \mathrm{def}$ \\
\hline PI657077 & GMAL4000.b & 6.00 bcdefgh & 5.00 bcde & $17.58 \mathrm{abcd}$ & 23.41 abcde \\
\hline PI657078 & GMAL4000.g & 6.43 abcdefgh & 4.78 bcde & $18.62 \mathrm{abcd}$ & 22.75 abcde \\
\hline PI657079 & GMAL4002.d & $5.36 \mathrm{efgh}$ & 3.75 def & $15.10 \mathrm{de}$ & 14.49 ef \\
\hline PI657080 & GMAL4002.e & 6.52 abcdefgh & 4.45 cde & $18.18 \mathrm{abcd}$ & 20.67 abcde \\
\hline PI657083 & GMAL4002.h & $6.25 \mathrm{bcdefgh}$ & $4.28 \mathrm{cde}$ & $17.82 \mathrm{abcd}$ & 19.53 abcde \\
\hline
\end{tabular}

${ }^{2}$ Five fully expanded leaves per individual tree were measured.

${ }^{y}$ Values with the same letters are not significantly different at the $P<0.05$ level using Ryan-Einot-GabrielWelsch multiple range test.

${ }^{x}$ The extreme values are underlined (highest values are double underlined; lowest values are single underlined). 
potting soil. These tissues were immediately frozen in liquid nitrogen. RNA was isolated and assessed for quality and genomic DNA contamination. RNA extraction and cDNA synthesis followed protocols described in Bassett et al. (2006). Suppression subtractive hybridization ( $\mathrm{SSH}$ ) was performed as previously indicated (Bassett et al., 2006) using cDNA from water deficit-treated trees $(40 \%$ of saturation for 2 weeks) as a tester and cDNAs from well-watered controls $(10 \times$ concentration) as driver. The final polymerase chain reaction products from the subtracted cDNAs were cloned and sequenced. Genes were identified with BLASTx and BLASTn (<http://www.ncbi.nlm.nih.gov>).

\section{RESULTS AND DISCUSSION}

Leaf characteristics of 'Royal Gala' and site 6.01 M. sieversii accessions. Our initial characterization of water deficit response in apple focused on leaves, bark, and roots of 'Royal Gala' because it is a commercially important cultivar and clonally propagated plant material (own-rooted material) is readily available for experimentation. The latter consideration is important for comparison
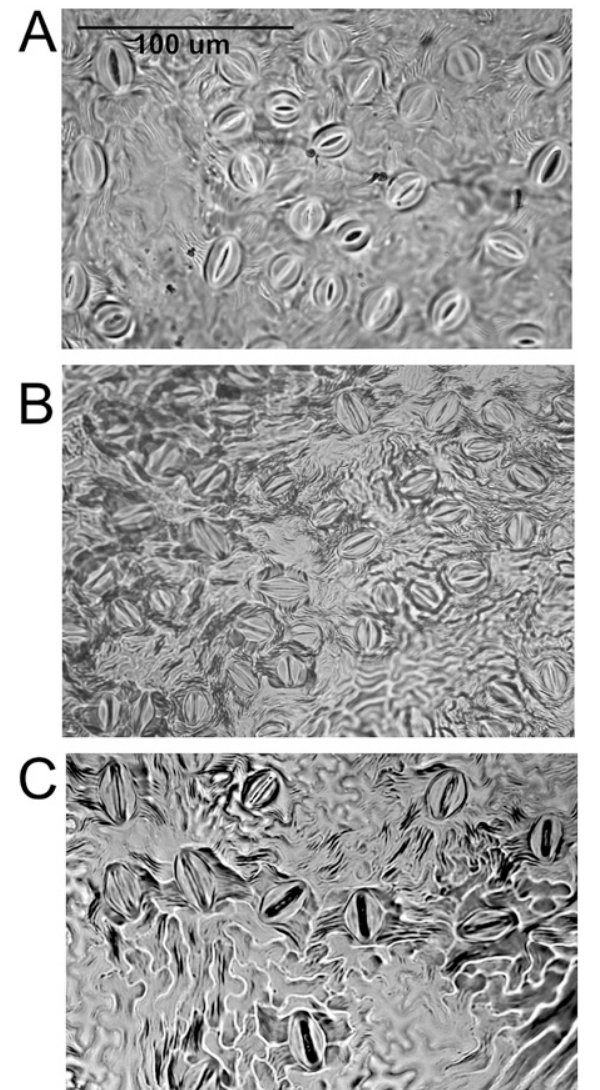

Fig. 1. Stomata density differences between $M$. sieversii individuals and 'Royal Gala'. Leaves at the same approximate position were collected from five branches of equal length. Stomata were preserved on slides as described in "Materials and Methods" and photographed with a PAXcam camera under a light microscope (40× magnification). (A) 'Royal Gala'; (B) PI 657029; (C) PI 657039. with $M$. sieversii accessions, which are seedderived trees in the orchard that can also be clonally propagated on their own roots (data not shown).

Some drought-resistant plants have leaf modifications that reduce water loss as a result of transpiration (Chaves et al., 2003; Larcher, 2000). These modifications include, but are not limited to, reduction in leaf surface area and/or thickness, changes in leaf number per branch or total canopy, and alterations in stomata morphology and trichome density (Sandquist and Ehleringer, 2003). Decreasing leaf area (including premature senescence and the shedding of older leaves) is a common response to water deficit and is thought to be related to the reallocation of nutrients to the stem and younger leaves (Khanna-Chopra et al., 1999). Likewise, leaf pubescence is important for productivity under hot, dry conditions because the highly reflective trichomes decrease absorption of solar radiation resulting in decreased heat load on a leaf (Ehleringer and Clark, 1988).

Studies of trees in different rainfall environments have shown that both morphological and physiological factors contribute to effective drought resistance. A study with eastern redbud trees (Cercis canadensis L.) grown in three different environments indicated that trees from the most xeric environment had smaller, thicker leaves compared with those from more mesic locales (Abrams, 1988). Likewise, Rieger et al. (2003) reported genotypic differences in leaf size and specific leaf area in peach species, and these differences correlated with the degree of dryness in the environment from which they originated. Like morphological variation, the accumulation of osmolytes as a response to drought and an aid in dehydration amelioration has been amply demonstrated (Arndt et al., 2001; Peltier et al., 1997; Wang and Stutte, 1992). All of these results taken together suggest that genetically controlled physiological and morphological factors have facilitated adaptation to contrasting habitats, particularly in temperate tree species.

To begin clarifying the contribution of leaf morphology differences to WUE and drought resistance parameters in this population, we documented leaf morphology traits in mature trees of $M$. sieversii and 'Royal Gala', including leaf area and perimeter, leaf length and width, and stomata length and density. Data from individual trees (Table 1) were assessed for differences in leaf parameters and correlation with WUE measurements (manuscript in preparation). GMAL3683.o

Table 2. Stomata traits among Malus sieversii individuals from Kazakhstan site 6.01 individuals. $^{\mathrm{z}}$

\begin{tabular}{|c|c|c|c|}
\hline Plant introduction ID & Old accession ID & $\begin{array}{l}\text { Stomata length }{ }^{z, y} \\
(\mu \mathrm{m})\end{array}$ & $\begin{array}{c}\text { Stomata density } \\
\text { (stomata per } 0.09 \mathrm{~mm}^{2} \text { ) }\end{array}$ \\
\hline PI657028 & GMAL3682.e & $20.36 \mathrm{~b}$ & $35.33 \mathrm{abc}$ \\
\hline PI657029 & GMAL3682.f & $22.74 \mathrm{ab}$ & $48.33 \mathrm{ab}$ \\
\hline PI657030 & GMAL3682.k & $24.00 \mathrm{ab}$ & $41.33 \mathrm{abc}$ \\
\hline PI657031 & GMAL3683.d & $25.80 \mathrm{ab}$ & $35.67 \mathrm{abc}$ \\
\hline PI657033 & GMAL3683.i & $21.60 \mathrm{ab}$ & $35.33 \mathrm{abc}$ \\
\hline PI657034 & GMAL3683.n & $22.02 \mathrm{ab}$ & $43.00 \mathrm{abc}$ \\
\hline PI657035 & GMAL3684.a & $20.17 b^{x}$ & $51.00 \mathrm{ab}$ \\
\hline PI657036 & GMAL3684.b & $\overline{26.85 \mathrm{a}}$ & $48.00 \mathrm{ab}$ \\
\hline PI657037 & GMAL3684.1 & $23.30 \mathrm{ab}$ & $33.33 \mathrm{bc}$ \\
\hline PI657038 & GMAL3685.d & $25.27 \mathrm{ab}$ & $37.67 \mathrm{abc}$ \\
\hline PI657039 & GMAL3685.e & $25.44 \mathrm{ab}$ & $23.33 \mathrm{c}$ \\
\hline PI657040 & GMAL3685.f & $24.44 \mathrm{ab}$ & $\overline{33.33 \mathrm{~b}} \mathrm{c}$ \\
\hline PI657042 & GMAL3687.d & $23.93 \mathrm{ab}$ & $32.33 \mathrm{bc}$ \\
\hline PI657045 & GMAL3688.n & $22.73 \mathrm{ab}$ & $37.67 \mathrm{abc}$ \\
\hline PI657046 & GMAL3689.c & $21.91 \mathrm{ab}$ & $37.67 \mathrm{abc}$ \\
\hline PI657049 & GMAL3689.n & $21.58 \mathrm{ab}$ & $58.00 \mathrm{a}$ \\
\hline PI657050 & GMAL3689.p & $22.68 \mathrm{ab}$ & $\overline{54.67 \mathrm{ab}}$ \\
\hline PI657051 & GMAL3690.d & $22.37 \mathrm{ab}$ & $33.00 \mathrm{bc}$ \\
\hline PI657052 & GMAL3690.o & $23.42 \mathrm{ab}$ & $37.33 \mathrm{abc}$ \\
\hline PI657055 & GMAL3691.j & $24.21 \mathrm{ab}$ & $40.33 \mathrm{abc}$ \\
\hline PI657056 & GMAL3691.m & $26.04 \mathrm{a}$ & $36.33 \mathrm{abc}$ \\
\hline PI657067 & GMAL3975.d & $\overline{22.99 \mathrm{ab}}$ & $36.33 \mathrm{abc}$ \\
\hline PI657068 & GMAL3975.g & $23.95 \mathrm{ab}$ & $42.33 \mathrm{abc}$ \\
\hline PI657069 & GMAL3975.k & $23.27 \mathrm{ab}$ & $36.5 \mathrm{abc}$ \\
\hline PI657070 & GMAL3975.1 & $23.41 \mathrm{ab}$ & $35.67 \mathrm{abc}$ \\
\hline PI657071 & GMAL3975.m & $22.51 \mathrm{ab}$ & $39.33 \mathrm{abc}$ \\
\hline PI657073 & GMAL3989.f & $24.84 \mathrm{ab}$ & $39.67 \mathrm{abc}$ \\
\hline PI657074 & GMAL3989.k & $23.93 \mathrm{ab}$ & $39.00 \mathrm{abc}$ \\
\hline PI657075 & GMAL3999.b & $25.42 \mathrm{ab}$ & $35.33 \mathrm{abc}$ \\
\hline PI657077 & GMAL4000.b & $22.68 \mathrm{ab}$ & $38.67 \mathrm{abc}$ \\
\hline PI657078 & GMAL4000.g & $21.23 \mathrm{ab}$ & $44.33 \mathrm{abc}$ \\
\hline PI657079 & GMAL4002.d & $24.37 \mathrm{ab}$ & $36.33 \mathrm{abc}$ \\
\hline PI657080 & GMAL4002.e & $23.51 \mathrm{ab}$ & $35.00 \mathrm{abc}$ \\
\hline PI657083 & GMAL4002.h & $22.29 \mathrm{ab}$ & $35.33 \mathrm{abc}$ \\
\hline
\end{tabular}

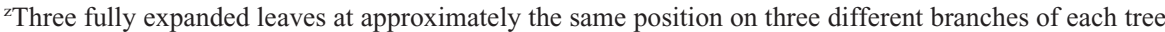
were measured.

${ }^{y}$ Values with the same letters are not significantly different at the $P<0.05$ level using Ryan-Einot-GabrielWelsch multiple range test.

${ }^{x}$ The extreme values are underlined (highest values are double underlined; lowest values are single underlined). 
was not part of the core diversity collection but was selected as an "outlier" because it appeared to have the smallest leaves of the entire site 6.01 collection. Indeed, statistical analyses indicated that it had the smallest leaf length and width and, hence, the smallest perimeter and area of all the individual trees examined. The largest leaf by area was found with PI657073 (GMAL3989.f), whereas PI657042 (GMAL3687.d) and PI657051 (GMAL 3690.d) had the longest length and width, respectively. As expected, some of the half-sibling groups (same GMAL number, different lower case letter) varied in one or more parameters (e.g., GMAL3975.d, which differed significantly in leaf width compared with its GMAL3975 half-siblings). Sandquist and Ehleringer (2003) in a study of leaf pubescence in Encelia farinosa also found substantial diversity in different populations that correlated with diverse environments and was thought to reflect adaptation to different rainfall conditions. Differences within a population such as we observed with the site $6.01 \mathrm{M}$. sieversii trees suggest a genetic basis that is likely related to environmental adaptation. These differences may persist because of relatively weak selection forces or because of the presence of dominant effects that overwhelm genes associated with a single, specific adaptive trait. Indeed, stomata effects typically predominate under moderate stress, but biochemical limitations are quantitatively more important during leaf aging or severe drought (Gallé et al., 2007; Grassi and Magnani, 2005). Furthermore, the complexity between structure and function during leaf development may mask the effects of environmental stresses such as drought and make interpretation of the effects of stress on leaf function and/or structure difficult (Schurr et al., 2000).

In the case of stomata density, differences between certain individuals were twofold or greater (Fig. 1; Table 2), whereas differences in stomata length were less dramatic. Stomata length extremes were observed within a half-sibling group (i.e., GMAL3684.b and 3684.a), whereas density extremes were observed between groups (i.e., PI657049 and PI657039). No significant correlation was observed between stomatal length or density and leaf area (data not shown).

It has been reported that differences in stomata density can occur as a result of drought severity. For example, Xu and Zhou (2008) showed that moderate drought treatment resulted in greater stomata density in a perennial grass, whereas a severe drought led to a decrease in density. Preliminary experiments with clonal replicates of PI657039 (lowest stomata density) suggest that it is relatively more sensitive to severe water deficit than 'Royal Gala' (data not shown). Future experiments will allow us to determine whether this is the case for M. sieversii collected from different Kazakhstan environments.

Analysis of genes upregulated in response to water deficit in 'Royal Gala'. Young trees of 'Royal Gala' were subjected to a stringent water deficit regime, i.e., $40 \%$ of the wellwatered condition for 2 weeks. Although apple is somewhat drought-resistant, 'Royal Gala' trees maintained under this water deficit regimen began to show signs of stress (Fig. 2). Typical symptoms of water deficit included the in-rolling of leaves to reduce surface area and death of the main shoot apex (Fig. 2D). In addition, measurements of net photosynthesis, stem water potential, and leaf osmotic potential were consistent with drought treatment responses in the experimental group (data not shown).

We identified a total of 149 genes upregulated in response to water deficit (Table 3 ). Genes from leaves and bark were associated for the most part with photosynthesis. Others have identified several classes of photosynthetic genes that are upregulated in response to water deficit as well as in response to other stresses (Bogeat-Triboulot et al., 2007; Boominathan et al., 2004). It is thought that upregulation of components of PSI and II could reflect adjustments to dissipate excess electrons generated during the stress period
(Öquist and Huner, 2003). In addition to increases in the chloroplast electron transport apparatus, increases in rubisco small subunit and rubisco activase have also been reported (Boominathan et al., 2004). This is consistent with the observation that leaves that survive drought often show higher content of rubisco/ unit leaf area than well-hydrated plants (David et al., 1998). Furthermore, it has been shown that leaves growing under drought become a carbon source at a smaller size than leaves in well-watered plants (Schurr et al., 2000).

It is also not surprising that numerous stressrelated genes are upregulated during the drought period, because there is considerable overlap in stress-responsive gene expression (e.g., Seki et al., 2002). We compared genes from roots, bark (primarily cambium), and leaves to identify tissue-specific genes and genes common to one or more tissues (Fig. 3). No stress-related genes common to all three tissues were detected. There were more genes common to leaves and bark than leaves and root or bark and root.
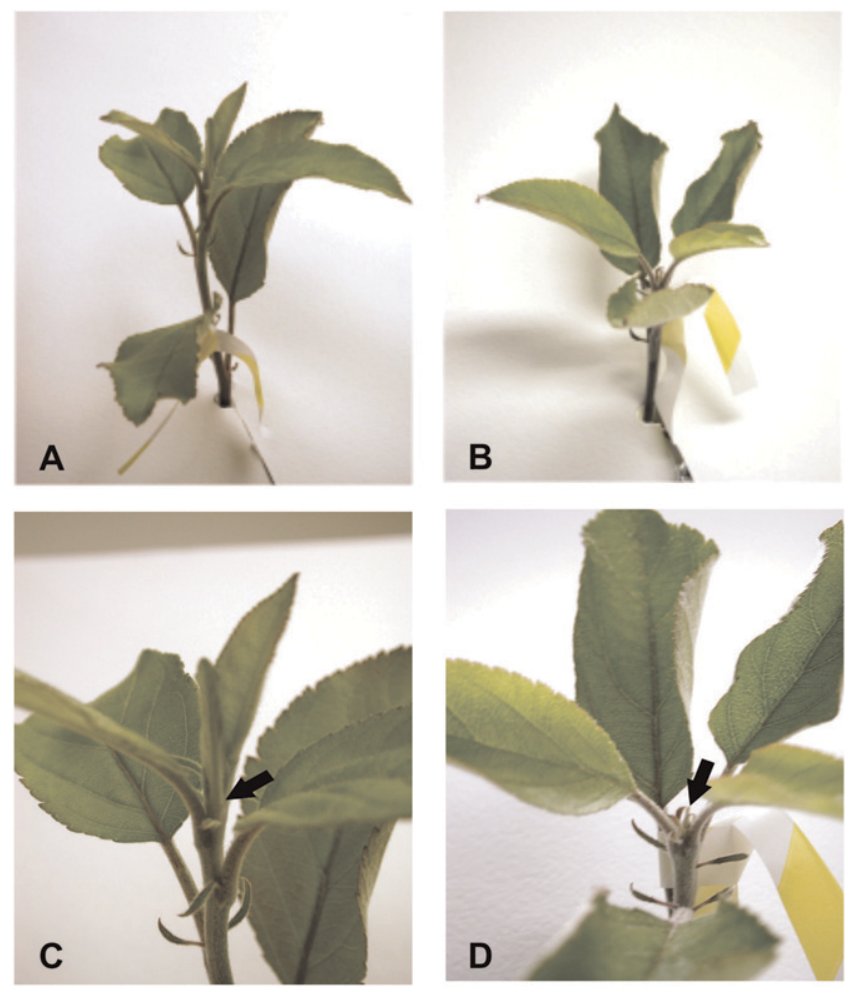

Fig. 2. Response of 'Royal Gala' to a severe water deficit. Trees of clonally replicated 'Royal Gala' shoots were grown in 15.25 -cm pots for 2 weeks in a climate-controlled growth chamber. Water was withheld from half of the individuals until pots reached $40 \%$ (by weight) of their pre-water deficit weight. The trees were kept at $40 \%$ saturation for 2 weeks, after which they were photographed and sampled for RNA extraction. (A, C) Well-watered controls (B, D) trees 2 weeks at $40 \%$ saturation. Arrows in the close-ups $(\mathbf{C}-\mathbf{D})$ indicate the shoot apex.

Table 3. Genes by biological process upregulated in 'Royal Gala' in response to drought.

\begin{tabular}{lccccc}
\hline & Total genes & \multicolumn{4}{c}{ Biological processes } \\
\cline { 2 - 6 } Tissue & isolated by SSH & Stress & Photosynthesis & Metabolism & Other $^{2}$ \\
\hline Root & 35 & 14 & 0 & 5 & 16 \\
Bark & 25 & 6 & 11 & 0 & 8 \\
Leaf & 89 & 17 & 41 & 11 & 20 \\
\hline
\end{tabular}

${ }^{2}$ Includes genes identified as hypothetical and genes with no match in the BLAST Viridiplantae nonredundant database.

$\mathrm{SSH}=$ suppression subtractive hybridization. 


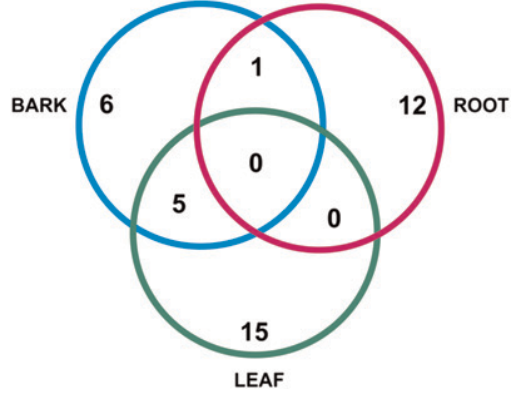

Fig. 3. Stress genes upregulated in 'Royal Gala' in response to water deficit. Young trees were subjected to 2 weeks of water deficit or were well-watered during that time (controls). SSH was performed with each tissue separately using the control cDNAs in 10-fold excess as a "driver" and the water deficit-treated cDNAs as a "tester." Genes were sequenced and identified by BLASTx or BLASTn. Shown are the numbers of unigenes representing stress-responsive genes that are upregulated in the different tissues. $\mathrm{SSH}=$ suppression subtractive hybridization .

Previous analysis of ESTs isolated from this same experiment also reported more genes unique to roots and leaves when tissue-specific control sequences were subtracted from the experimental ESTs (Wisniewski et al., 2008). $\mathrm{We}$ are currently analyzing the sequences obtained from the SSH experiments to identify more completely those genes that comprise families with similar sequences (identities) but diverse functions. In addition, we plan to align all the hypothetical and predicted genes to see if any of these genes are unique or common to the tissues analyzed here. The first step in correlating differences in gene structure or expression with adaptation to dry environments is to identify those genes that are up- and downregulated in response to drought. To this end, we are clonally propagating select $M$. sieversii lines to test for drought resistance under controlled water deficit conditions. Information obtained from these studies can be applied to breeding programs to enhance survival of important commercial cultivars of apple during periods of drought.

\section{Literature Cited}

Abrams, M.D. 1988. Genetic variation in leaf morphology and plant and tissue water relations during drought in Cercis canadensis $\mathrm{L}$. For. Sci. 34:200-207.

Adams, H.D., M. Guardiola-Claramonte, G.A Barron-Gafford, J.C. Villegas, D.D. Breshears, C.B. Zou, P.A. Troch, and T.E. Huxman. 2009. Temperature sensitivity of drought-induced tree mortality portends increased regional die-off under global-change-type drought. Proc. Natl. Acad. Sci. USA 106:7063-7066.

Arndt, S.K., S.C. Clifford, W. Wanek, H.G. Jones, and M. Popp. 2001. Physiological and morphological adaptations of the fruit tree Ziziphus rotundifolia in response to progressive drought stress. Tree Physiol. 21:705-715.

Bassett, C.L., M.E. Wisniewski, T.S. Artlip, J.L. Norelli, J. Renaut, and R.E. Farrell, Jr. 2006. Global analysis of genes regulated by low temperature and photoperiod in peach bark. J. Amer. Soc. Hort. Sci. 131:551-563.
Blum, A. 2005. Drought resistance, water-use efficiency, and yield potential-Are they compatible, dissonant or mutually exclusive? Aust. J. Agr. Res. 56:1159-1168.

Bogeat-Triboulot, M.-B., M. Brosché, J. Renaut, L. Jouve, D. Le Thiec, P. Fayyaz, B. Vinocur, E. Witters, K. Laukens, T. Teichmann, A. Altman, J.-F. Hausman, A. Polle, J. Kangasjärvi, and E. Dreyer. 2007. Gradual soil water depletion results in reversible changes of gene expression, protein profiles, ecophysiology, and growth performance in Populus euphatica, a poplar growing in arid regions. Plant Physiol. 143:876-892.

Bolar, J.P., V. Hanke, J.L. Norelli, and H.S Aldwinckle. 1998. An efficient method for rooting and acclimation of micropropagated apple cultivars. HortScience 33:1251-1252.

Boominathan, P., R. Shukla, A. Kumar, D. Manna, D. Negi, P.K. Verma, and D. Chattopadhyay. 2004. Long term transcript accumulation during the development of dehydration adaptation in Cicer arietinum. Plant Physiol. 135:16081620.

Breshears, D.D., N.S. Cobb, P.M. Rich, K.P. Price, C.D. Allen, R.G. Balice, W.H. Romme, J.H Kastens, M.L. Floyd, J. Belnap, J.J. Anderson, O.B. Myers, and C.W. Meyer. 2005. Regional vegetation die-off in response to global-changetype drought. Proc. Natl. Acad. Sci. USA 102: 15144-15148.

Chaves, M.M., J.P. Maroco, and J.S. Pereira. 2003. Understanding plant responses to droughtFrom genes to the whole plant. Funct. Plant Biol. 30:239-264.

Cooter, E.J. and S.K. Leduc. 1995. Recent frost date trends in the north-eastern USA. Int. J. Climatol. 15:65-75.

Dai, A., K.E. Trenberth, and T.R. Karl. 1998 Global variations in droughts and wet spells: 1900-1995. Geophys. Res. Lett. 25:3367-3370.

David, M.M., D. Coelho, I. Barrote, and M.J. Correia. 1998. Leaf age effects on photosynthetic activity and sugar accumulation in droughted and rewatered Lupinus albus plants. Aust. J. Plant Physiol. 25:299-306.

Easterling, D.R., G.A. Meehl, C. Parmesan, S.A. Changnon, T.R. Karl, and L.O. Mearns. 2000. Climate extremes: Observations, modeling, and impacts. Science 289:2068-2074.

Ehleringer, J.R. and C. Clark. 1988. Evolution and adaptation in Encelia (Asteraceae), p. 221-248. In: Gottlieb, L.D. and S.K. Jain (eds.). Plant evolutionary biology. Chapman and Hall, New York, NY

Forsline, P.L., H.S. Aldwinckle, E.E. Dickson, and S.C. Hokanson. 2003. Collection, maintenance, characterization and utilization of wild apples from central Asia, p. 1-62. In: Janick, J. (ed.). Horticultural reviews. Amer. Soc. Hort. Sci., Arlington, VA.

Gallé, A., P. Haldimann, and U. Feller. 2007. Photosynthetic performance and water relations in young pubescent oak (Quercus pubescens) trees during drought stress and recovery. New Phytol. 174:799-810.

Glenn, D.M. and C. Bassett. 2011. Apple $\Delta^{13} \mathrm{C}$ discrimination is related to shoot ash content. HortScience 46:213-216.

Grassi, G. and F. Magnani. 2005. Stomatal, mesophyll conductance and biochemical limitations to photosynthesis as affected by drought and leaf ontogeny in ash and oak trees. Plant Cell Environ. 28:834-849.

Harris, S.A., J.P. Robinson, and B.E. Juniper. 2002. Genetic clues to the origin of the apple. Trends Genet. 18:426-430.

Jinghui, Y., Y. Enqin, and Y. Huanting. 1996. A study on drought resistance of genus Malus seedling. Acta Agr. Boreali-Sinica China. 2: 81-86.

Khanna-Chopra, R., B. Srivalli, and Y.S. Ahlawat. 1999. Drought induces many forms of cysteine proteases not observed during natural senescence. Biochem. Biophys. Res. Commun. 255: 324-327.

Ko, K., J.L. Norelli, J.-P. Reynoird, H.S. Aldwinckle, and S.K. Brown. 2002. T4 lysozyme and attacin genes enhance resistance of transgenic 'Galaxy' apple against Erwinia amylovora. J. Amer. Soc. Hort. Sci. 127:515-519.

Larcher, W. 2000. Temperature stress and survival ability of Mediterranean sclerophyllous plants. Plant Biosyst. 134:279-295.

Mabberley, D.J., C.E. Jarvis, and B.E. Juniper. 2001 The name of the apple. Telopea 9:421-430.

Nabhan, G. 2008. The fatherland of apples. Orion 27:32-37.

Norelli, J.L., H.S. Aldwinckle, and S.V. Beer. 1988. Virulence of Erwinia amylovora strains to Malus sp. Novole plants grown in vitro and in the greenhouse. Phytopathology 78:1292-1297.

Öquist, G. and N.P. Huner. 2003. Photosynthesis of overwintering evergreen plants. Annu. Rev. Plant Biol. 54:329-355.

Peltier, J.P., D. Marigo, and G. Marigo. 1997. Involvement of malate and mannitol in the diurnal regulation of the water status in members of Oleaceae. Trees (Berl.) 12:27-34.

Rieger, M., R. Lo Bianco, and W.R. Okie. 2003. Responses of Prunus ferganensis, Prunus persica and two interspecific hybrids to moderate drought stress. Tree Physiol. 23:51-58.

Robinson, J.P., S.A. Harris, and B.E. Juniper. 2001 Taxonomy of the genus Malus Mill (Rosaceae) with emphasis on the cultivated apple, Malus domestica Borkh. Plant Syst. Evol. 226:35-58.

Sandquist, D.R. and J.R. Ehleringer. 2003. Population- and family-level variation of brittlebush (Encelia farinosa, Asteraceae) pubescence: Its relation to drought and implications for selection in variable environments. Amer. J. Bot. 90:1481-1486.

Savé, R., C. Biel, and F. de Herralde. 2000. Leaf pubescence, water relations and chlorophyll fluorescence in two subspecies of Lotus creticus L. Biol. Plant. 43:239-244.

Schurr, U., U. Heckenberger, K. Herdel, A. Walter, and R. Feil. 2000. Leaf development in Ricinus communis during drought stress: Dynamics of growth processes, of cellular structure and of sink-source transition. J. Expt. Bot. 51:1515-1529.

Seki, M., M. Narusaka, J. Ishida, T. Nanjo, M. Fujita, Y. Oono, A. Kamiya, M. Nakajima, A. Enju, T. Sakurai, M. Satou, K. Akiyama, T. Taji, K. Yamaguchi-Shinozaki, P. Carninci, J. Kawai, Y. Hayashizaki, and K. Shinozaki. 2002. Monitoring the expression profiles of 7000 Arabidopsis genes under drought, cold and high-salinity stresses using a full-length cDNA microarray. Plant J. 31:279-292.

Veslaco, R., A. Zarkikh, J. Affourtit, A. Dhingra, A. Cestaro, A. Kalyanaraman, P. Baldi, S Castelletti, M. Cavaiuolo, G. Coppola, F. Costa, V. Cova, A. Dal Ri, V. Goremykin, M. Komjanc, S. Longhi, P. Magnago, G. Malacarne, M. Malnoy, D. Micheletti, M. Moretto, M. Perazzolli, A. Si-Ammour, S. Vezzuli, E. Zini, G. Eldredge, L.M. Fitzgerald, N. Gutin, J. Lanchbury, T. Macalma, J.T. Mitchell, J. Reid, B. Wardell, C. Kodira, Z. Chen, B. Desany, F. Niazi, M. Palmer, T. Koepke, D. Jiwan, S. Schaeffer, V. Krishnan, C. Wu, V.T. Chu, S.T King, J. Vick, Q. Tao, A. Mraz, A. Stormo, K. Stormo, R. Bogden, D. Ederle, A. Stella, A. Vecchietti, M.M. Kater, S. Masiero, P. Lasserre, Y. Lespinasse, A.C. Allan, V. Bus, D. Chagné, 
R.N. Crowhurst, A.P. Gleave, E. Lavezzo, J.A. Fawcett, S. Proost, P. Rouzé, L. Sterck, S. Toppo, B. Lazzari, R.P. Hellens, C.-E. Durel, A. Gutin, R.E. Bumgarner, S.E. Gardiner, M. Skolnick, M. Egholm, Y. Van de Peer, F. Salamini, and R. Viola. 2010. The genome of the domesticated apple (Malus $\times$ domestica Borkh.). Nat. Genet. 42:833-839.

Volk, G.M., C.M. Richards, A.A. Reilley, A.D. Henk, P.L. Forsline, and H.S. Aldwinckle. 2005. Ex situ conservation of vegetatively propagated species: Development of a seed-based core collection for Malus sieversii. J. Amer. Soc. Hort. Sci. 130:203-210.

Wang, Z. and G.W. Stutte. 1992. The role of carbohydrates in active osmotic adjustment in apple under water stress. J. Amer. Soc. Hort. Sci. 117:816-823.

Wisniewski, M., C. Bassett, J. Norelli, D. Macarisin, T. Artlip, K. Gasic, and S.W. Korban. 2008 Expressed sequence tag analysis of the response of apple (Malus $\times$ domestica 'Royal Gala') to low temperature and water deficit. Physiol. Plant. 133:298-317.
Xu, Z. and G. Zhou. 2008. Responses of leaf stomatal density to water status and its relationship with photosynthesis in a grass. J. Expt. Bot. 59:3317-3325.

Yan, G., H. Long, W. Song, and R. Chen. 2008. Genetic polymorphism of Malus sieversii populations in Xinjiang, China. Genet. Resources Crop Evol. 55:171-181.

Zhou, Z.Q. and Y.N. Li. 2000. The RAPD evidence for the phylogenetic relationship of the closely related species of cultivated apple. Genet. Resources Crop Evol. 47:353-357. 